\title{
SET for Quality in Sport: See - Experience - Transcend 遝尚優質體育：曲觀看到體驗至超越
}

\author{
John S.C. Li \\ Leisure Pro \\ Association for Group Recreational Activities, HONG KONG
}

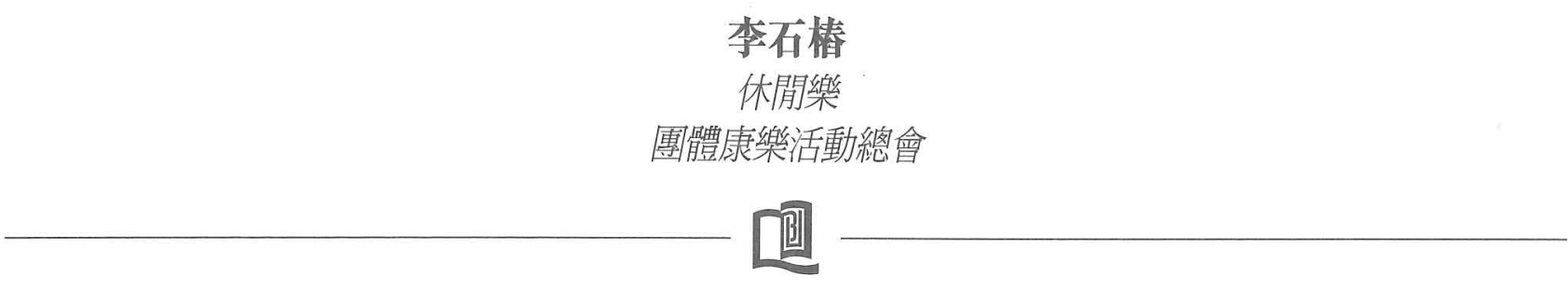

\begin{abstract}
Quality' is a word used very often at work and in delivering services to clients. However, judgement on quality is very subjective and judgement can only be made when one sees it or experiences it. It is not uncommon that there are many views from different people on quality of the same service or product. As a sport service agent, we want to evaluate our service achievement to ensure our quality. Quality measurement is a means to meet this purpose. This measurement is not just measured by the number of participants, the number of medals achieved, or whether a break-even account statement is attended. It is also important to conform to the standards, requirements, regulations, policies, procedures, and goals that are set for the services. The feedback from the participants and impact of the services to the society are also elemental to quality service. In sport, quality improvement begins with hardware - facilities, equipment, apparel - which people can easily SEE the difference. In the second stage, the software - professional coaches, administrators, quality programs and outstanding performance let people EXPERIENCE a change. The ultimate development and the beauty of sport, however, are the shared sporting spirit which TRANSCEND the essence of human being. This paper will focus on how SET is applied in current sport development in Hong Kong and to elevate the quality of sport into the year 2000 and beyond.
\end{abstract}

\section{摘要}

個人對服務質素的要求因人而異, 對服務的滿意程度亦須使用者親身看過或切身體驗後才可作出主觀評論。體育專業人員 的工作目標是爲公衆人仕及運動員提供優質體育活動。用以評訂體育工作的成效, 普遍以參加人數、獎牌數目、及賬目收支本 衡作爲評審準則。客觀的評核應以共同爲體育設訂的理想、標準、要求、規則、政策、程序及目標鹞指標。體育質數的提昇有 一定的進程, 通常體育發展多由爲人看到的硬件項目開始, 如改善運動設施、器材、政策等。繼而開展軟件項目, 如聘請優質 數的教練及體育行政人員, 提供多元化活動及後勤服務, 務使參加者能親身體驗優質體育活動。體育發展的最終目標是希望能 多將體育精神超越體育, 使參加者能應用體育的經驗及精神於日常生活及工作裡。本文探索香港在「觀看」到「體驗」至「超 越」的體育發展進程, 逐步邁向優質體育的理想。

\section{Introduction}

'Quality' is a word very often used by management in differentiating good service or product over those not so good through direct 'apple to apple' comparison or matching products or services with the agreed standards and guidelines. Many organizations communicate their concerns and commitments to quality through performance pledge. It serves to provide assurance and confidence to consumers, and educate and alert employees what is expected in their job performance.

In Hong Kong (HK), many governmental departments have developed performance pledge in their services. For instance, the Department of Health has a vision to "provide quality clientoriented service" (HK SAR Gov't - Health Department, 1998); the Education Department pledges to "provide quality school education for our students" (HK SAR Gov't - Education Department, 1998); and the Social Welfare Department is committed to "providing high quality and professional service with courtesy, fairness, confidentiality, promptness and personal concern" (HK SAR Gov't - Social Welfare Department, 1998).

What does 'Quality' actually mean in these pledges to consumers and services? To consumers, quality means satisfaction 
and value for money. To management, quality is about care, commitment, and reinforcement in word of mouth and re-purchasing behavior. Management concerned with 'Quality' will encourage employees to seek ways to understand customers' perceptions, strive hard to satisfy customers' expectations, and look for continuous improvement (Stores, 1991). Quality is then the expectations from people and should be measurable in order to create satisfaction and find better ways for improvement. Expectations, rules, standards, requirements, regulations, policies, procedures, commitments and goals should be set as the yardstick of the organization to measure quality and the same should be communicated to consumers and employees.

\section{Quality in Sport}

Sport is universal and always aims at quality. Quality in sport means continuous strive for advancement and achievement in every respect. These include provision of sporting facilities and equipment; good policy and financial support; excellent performance by athletes; excitement among sport fans; and finally the transcending of sport spirits among all participants, athletes and spectators alike. In every corner of the world, people play hard in sport for personal health or achievement, for team success or for the glory of one's country. In sport, quality is maintained under universal rules and standards. The essence of rules and standards in sport is to provide a fair, safe and enchanting environment for athletes to compete and perform for excellence.

Sport development is advancing every day and has become a big business that provides a lot of jobs, market opportunities, profits, entertainment, cohesion, and advancement. Today, bigger sport arenas are built with more advanced equipment installed. Sport events are better packaged and more excitement and fun are provided. More sports are developed from amateur sport into professional sport and new records are set with the advancement in training techniques and equipment.

\section{Three Pillars of Quality}

Quality can be seen, experienced and transcended when it exceeds one's expectations. The strengths of the three pillars - See, Experience, and Transcend - SETs the milestone for quality. We can use the three pillars of quality to understand the levels of sport development.

\section{SEE the Quality in Sport}

In sport, quality that can be seen includes sport facilities, equipment, policy, finance, structure, and programs. The basic quality is to meet the expectations, standards and guidelines adopted by international and local sporting organizations.
Hosting countries of the Olympic Games receive strict sanction by the Olympic Committee. Guidelines and standards are strictly used to assess the eligibility of the bidding countries every four years to guarantee top quality infrastructure, programs and services in the Games. Hong Kong does not have the required infrastructures, expertise and manpower to bid for the Games but is capable to host some major championships. Hong Kong has successfully hosted the 2nd World Dragon Boat Championships, the 1st World Doubles Squash Championships, the 13th World and 6th Women's World Taekwondo Championships, the World Rugby Seven, and the Asian Youth Cricket Championships in 1997.

The success of the functions proves that Hong Kong has up to standard sport infrastructure for individual sport competition and local public use. The Planning Standards and Guidelines (HKPSG) developed in 1981 aims to assure the basic infrastructures of sport and recreation facilities in each district be provided according to the population in the district (Llewelyn-Davies HK, 1997). In 1998, a review was completed and recommendations were made to accommodate changes in demographic structure and socio-economic characteristics. New provisions in gymnasium, leisure swimming pool, grass pitch for rugby, baseball, and cricket were recommended (Llewelyn-Davies HK,1997). However, good looking and well-equipped stadium can be ruined by many other factors. The poor grass pitch in Hong Kong Stadium is an example. It has disappointed many teams and players. This very well illustrates that facility provision in place will not meet the standard for good quality unless the construction and maintenance adhere to the standards and guidelines by experienced and responsible personnel.

In the provision of sporting equipment, Hong Kong does not have innovative sport equipment designer and producer. All hi-tech equipment has to be imported from other countries. However, since Hong Kong is an open market, sporting equipment of the latest design and best quality are readily available in Hong Kong.

Good sport policy and structure with congenial local and international relationships lay the foundation for all parties involved in the pursuit for sport excellence. The expanding government funding for the Hong Kong Sports Development Board (SDB) from HK\$31.47 million in 1991-92 to HK\$237.19 million in 1998-99 is a good indicator of the commitment of the Special Administrative Region (SAR) government to sport development in Hong Kong. The preservation of the sporting identity of Hong Kong after the handover of sovereignty on 1 July 1997 provides further opportunities to athletes in making continued achievement on the international stage. SDB's 5-year strategic plans published in 1991 and 1995 coupled with the 5-year plan of the two municipal councils in 1997 have moved local sport ahead in 
a clear and responsible direction. SDB also sponsors and organizes many exchange programs, international conferences, seminars and liaison meetings to maintain close contacts with international and local sport organizations and personnel. It also conducts researches, presents papers, and publishes newsletters and research reports to alert interested parties of the latest news and developments relating to sport.

Many funding and award schemes are in place to recognize athletes, coaches, and sponsors' contribution. Some of these include the Athlete of the Month Award and the Coca-Cola Sports Stars Awards of the Year for outstanding athletes. Coaches and sponsors are recognized through the Hong Kong Bank Foundation Coaching Awards and the Excellence Sports Marketing Awards respectively. Cash Incentive Scheme, the Sports Aid Foundation Fund, the Sports Aid for the Disabled Fund, the Scholarship Scheme, and the Athlete Fund provide incentives and financial assistance to elite and youth athletes. These funding and awards also serve to motivate program organizers, coaches and sponsors to provide quality sport programs, and to nurture potential athletes to best represent Hong Kong in international sport arena.

The SEE pillar in quality of sport depends on the vision, goals, expectations, standards, guidelines, and requirements set for the facilities, equipment, policy, goals, structure, finance, and programs according to international standards and requirements. Any attempt to exceed these goals, standards and requirements are aiming for an even better and pristine quality that exceed customers' expectations. Brilliant design facilities, hi-tech equipment, creative and sound policy, incentive schemes, encouraging records and performance, or some new and positive support to athletes, would definitely advance a step further in sport quality.

\section{EXPERIENCE the Quality in Sport}

Experience the quality in sport can only be obtained through participation and involvement. One can also experience quality sport simply watching the games as a spectator. Through participation and involvement in sport, one has the direct feeling and attachment to the sport. Experience is personal and the feelings are very subjective. Athletes and players will have different experiences in the same game or sport lesson, because they are affected by different factors in the game. There are two major factors that affect one's quality experience in sport. First, the external factors that one has little control, for example, weather, time, venue, equipment, coach, partners, opponents, rules and regulations, incentives, spectators and atmosphere. Second, the internal factors that one has more control, such as psychological and physical readiness, relationship with partners and the coach, self-confidence, courage, faith, commitment, personal strength, endurance, emotional control, and personal goals.
A quality match is a fair match and the basic requirement for a fair match is an environment that emphasizes equality among all players, including standard rules and regulations, independent referees, comparable equipment used by players, similar conditions on the field, equal number of players, and players are in compatible standard. However, given the above factors, a match may not be entertaining if the standard and performance of the players or teams are below one's expectation. The Division A soccer matches in Hong Kong serves a good example. All matches were conducted in a fair way, however, team performance is often below spectators' expectations. Football fans therefore become less avid with the live matches. Gate-tickets drop significantly to a new low level in the 1997-98 football season (HKFA, 1998).

People in Hong Kong are generally passive to sport. It may be the social culture in that priority is placed on study and work first and home entertainment second. Sport is not a necessary part of their daily activities. In nurturing elite athletes to strive for sport excellence, we need to broaden grass-root sport development and to arouse public concern to sport. There is a need to develop a more holistic system by providing training at junior level to elite squad. Popular and incentive programs are provided by the SDB and the two municipal councils in motivating grass-root people to participate in sport. Community Sports Clubs, District Sports Clubs, private and non-profit sport organizations, and the HK School Sports Federation maintain youth and adult players' interest in sport by providing stable practice, coaching and competition opportunities. The major responsibility of national sport associations (NSAs) is to identify potential athletes, organize training for them, select outstanding athletes to receive professional training and to represent Hong Kong in international competitions.

Quality training programs are affected by the quality of coaches and supportive services. Many national coaches in Hong Kong are recruited from other countries. This reflects the lack of local professional coaches. The Hong Kong Coach Accreditation Program introduced in 1991 has steadily trained and developed local coaches. The supportive services of sport science and medicine for elite athletes in the Sports Institute are not sufficient and more resources in this area are required to support elite squad training and prepare them for high level competitions.

Quality and commitment of sport policy makers, personnel, administrators, and coaches definitely affect the quality of sport development in Hong Kong. A comprehensive staff development plan is required to advance sporting knowledge in relation to international sporting policy, structure, junior development programs, sport clubs management, sporting culture development, and sport facilities development and management. Cooperation of all individual 
sport entities to elevate Hong Kong's international sport profile is important. This will create jobs in local sport market and generate income for tourist industry through international sport events hosted in Hong Kong.

\section{TRANSCEND the Quality in Sport}

The ultimate achievement in quality sport is to transcend sport spirits to other areas of practice. There are many unique sport spirits that are very valuable to personal character and attitude development which cannot be learnt from books or in the classroom without personally experiencing the essence of the spirit. These include optimism, quality orientation, strive for excellence, fair play, team spirit, courage, enthusiasm, commitment, hard work, confidence and entrepreneurship. All these characteristics and attitudes can be transcended and become one's personal attitude and character which can be applied to one's daily living, work, and study.

There are many retired athletes who lead a successful career in their sport career. Some of them, upon retirement, make good use of their sport experience and skills by taking up coaching and training potential athletes. Others build on what they have acquired in sport and transcend to their future career. Hong Kong people are being commended as very task oriented. People who are sport-oriented are often filled with enthusiasm, courage and optimism, and are hard working and goal oriented. They could do well and apply what they have learnt in sport into their future career. This transcending of sporting experience usually has a greater advantage over those who do not have sport background.

\section{Conclusion}

We can see that sport facilities, human resources, and funding sources have undergone progressive improvement and have steadily moved forward to make Hong Kong become a sporting center in the Southeast Asian region. Improved support from the special administrative government and close relationship with sport bodies in mainland China have significant impacts in sport development in Hong Kong.

Sport development in Hong Kong is still in its infancy. Although athletes have better performance in international sport arena, it still depends heavily on foreign coaches, provision of funds to support potential and elite athletes, and the development of career prospect for retired athletes. Public support to sport is weak and attendance rate to sport matches is low. There are lots of room for improvement: (1) to build more sport grounds and stadia for squad training and hosting of international competitions; (2) to make use of the school sport grounds in non-school hours to provide additional sport grounds for community sport development; (3) to increase sport participation through improving schools sport policy and incentive scheme for inactive citizens; (4) to train and provide career opportunities for local coaches; and (5) to develop professional sporting career for retired athletes and trained sport professionals.

We have seen a significant change in the quality of sport facilities in Hong Kong. However, the experience and transcending of quality in sport is still weak and it should deserve more public attention. How to make improvement in these areas is a challenging job for the sport professionals in Hong Kong. Without great visions and the foundation of quality sport experience, quality in sport cannot be attained and efforts made will not receive the desired returns.

\section{References}

Llewelyn-Davies Hong Kong (1998). Study of leisure habits and recreation preferences and review of chapter 4 of the Hong Kong Planning Standards and Guidelines - Executive Summary. Planning Department Hong Kong.

Hong Kong Football Association Ltd. (1998). Annual Report 1997-98. HKFA.

Hong Kong Special Administrative Government (1998). Mission Statement, Department of Health [Online]. Available: http:/ /www.info.gov.hk/dh/mission/index.htm (1998, May 17).

Hong Kong Special Administrative Government (1998). Mission Statement, Education Department [Online]. Available: http:/ /www.info.gov.hk/ed/ (1998, May 17).

Hong Kong Special Administrative Government (1998). Mission Statement, Social Welfare Department [Online]. Available: http://www.info.gov.hk/swd/index.htm (1998, May 17).

Stores, A (1991). Quality assurance in sport and leisure. In the Scottish Sports Council (1992) Proceedings of Sports and Leisure Scotland Conference 1991 - Towards a quality future. Scotland: Sport and Leisure Scotland. 